\title{
SEDIMENTOLOGIA DOS DEPÓSITOS CENOZÓICOS CONTINENTAIS DO BAIXO VALE DO RIO RIBEIRA DO IGUAPE, SP
}

\author{
Maria Cristina de MORAES \\ Sandra Garcia GABAS \\ Mário Sérgio de MELO \\ Luiz Alberto FERNANDES \\ Armando Márcio COIMBRA
}

\begin{abstract}
RESUMO
Estudos recentes conduziram à redefinição da Formação Pariqüera-Açu (Terciário continental do baixo Ribeira do Iguape), dividindo-a nas seguintes unidades independentes entre si: Formação Sete Barras, Formação Pariqüera-Açu, cascalhos em nível topográfico superior de terraços, cascalhos em nível intermediário de terraços e depósitos colúvio-aluviais. Esta subdivisão baseou-se em critérios litológicos, relações estratigráficas, distribuição em área e relações com feições tectônicas e geomorfológicas. Neste artigo são apresentados os principais dados sedimentológicos (análises granulométricas, minerais pesados e minerais de argila) que apoiaram a redefinição da Formação Pariqüera-Açu e a interpretação da evolução tectono-sedimentar cenozóica da área. Eles permitiram interpretar os processos envolvidos na sedimentação dos depósitos: somente tração para os cascalhos dos dois níveis de terraços; tração, fluxos densos (corridas de lamas) e suspensão para todas as outras unidades. Mostraram que a maior imaturidade mineralógica é apresentada justamente pelos cascalhos. Mostraram também que argilas esmectíticas ocorrem somente em sedimentos da Formação Sete Barras. Estes resultados subsidiaram a interpretação dos sistemas deposicionais envolvidos na sedimentação e forneceram indícios sobre o clima reinante à época.
\end{abstract}

\begin{abstract}
Recent studies on continental deposits that occur at the lower Ribeira do Iguape river valley (southern State of São Paulo, Brasil), led to the recognition of five different stratigraphic units, namely: the Sete Barras Formation, the Pariqüera-Açu Formation, two levels of fluvial terraces, and colluvial-alluvial deposits. All these sediments were formerly attributed to the Pariqüera-Açu Formation (with stages I, II and III), considered to be Pleistocene. This paper presents the stratigraphic and sedimentological data which support the re-definition of the Pariqüera-Açu Formation. Field work and grainsize analysis allowed to determine the main sedimentary processes for each unit. Maturity of heavy-minerals and nature of clays support the interpretation of paleoclimates. Both processes and paleoclimates pointed toward probable depositional systems and Cenozoic evolution of the area.
\end{abstract}

\section{INTRODUÇÃO}

Os depósitos da Formação Pariqüera-Açu, definida por BIGARELLA \& MOUSINHO (1965), foram recentemente objeto de estudos visando elucidar a evolução tectono-sedimentar continental cenozóica da área do baixo vale do Rio Ribeira do Iguape, na porção sul do Estado de São Paulo (MELO, 1990; MELO et al., 1990a e 1990b).

Este artigo objetiva apresentar os dados sedimentológicos e suas interpretações, os quais permitiram redefinir a Formação Pariqüera-Açu e propor modelo evolutivo cenozóico para a área.

\section{ESTRATIGRAFIA E SEDIMENTAÇÃO}

Os depósitos cenozóicos na área estudada compreendem não só todos os diferentes tipos de sedimentos terciários a quaternários atribuídos à Formação Pariqüera-Açu na Bibliografia preexistente, como também o complexo de sedimentos quaternários, variando de aluviais (ao longo dos vales dos principais rios) a costeiros (ao longo das extensas planícies costeiras da área).

As características faciológicas dos sedimentos, bem como suas relações estratigráficas, distribuição em área, associação com as feições tectônicas e geomorfológicas, permitiram agru- 


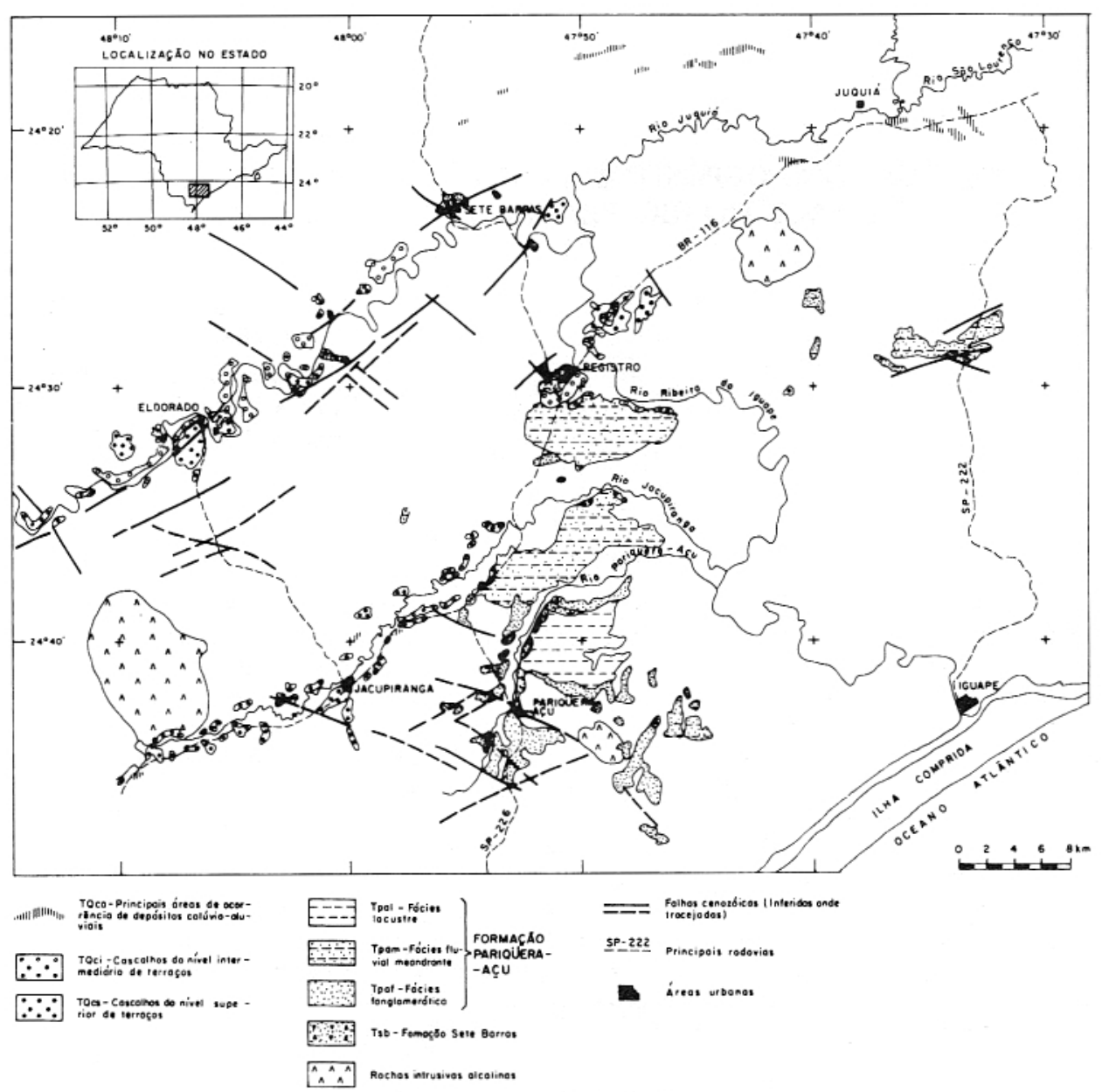

FIGURA 1 - Formação Pariqüera-Açu e depósitos relacionados.

QUADRO 1 - Terminologia adotada na classificação dos sedimentos cenozóicos continentais do baixo Ribeira do Iguape.

\begin{tabular}{|c|c|c|}
\hline \multirow{4}{*}{ 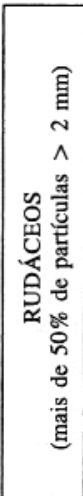 } & $\begin{array}{l}\text { CASCALHOS } \\
\text { (menos de } 15 \% \\
\text { de matriz fina) }\end{array}$ & $\begin{array}{l}\text { Inconsolidados, marcante arranjo interno } \\
\text { dos clastos, estes arredondados; formados } \\
\text { a partir da ação d'água com alta energia. }\end{array}$ \\
\hline & $\begin{array}{l}\text { ORTOCON- } \\
\text { GLO- } \\
\text { MERADOS } \\
\text { (menos de 15\% } \\
\text { de matriz fina) }\end{array}$ & $\begin{array}{l}\text { Mais consolidados que os cascalhos, no } \\
\text { restante semelhantes a eles. }\end{array}$ \\
\hline & $\begin{array}{l}\text { PARACON- } \\
\text { GLO- } \\
\text { MERADOS } \\
\text { (mais de } 15 \% \\
\text { de matriz fina) }\end{array}$ & $\begin{array}{l}\text { Clastos maiores arredondados e angulo- } \\
\text { sos dispersos aleatoriamente na abundan- } \\
\text { te matriz fina; formados a partir de } \\
\text { transporte de massa (fluxo de alta visco- } \\
\text { sidade ou fluxo denso). }\end{array}$ \\
\hline & BRECHAS & $\begin{array}{l}\text { Clastos angulosos; no restante semelhan- } \\
\text { tes aos paraconglomerados; formados a } \\
\text { partir de transporte de massa associado } \\
\text { a escarpas de falhas ativas. }\end{array}$ \\
\hline \multicolumn{2}{|c|}{$\begin{array}{c}\text { LAMITOS } \\
\text { (mais de } 50 \% \text { de } \\
\text { matriz } \\
\text { fina e mais de } 15 \% \\
\text { de areia e/ou partícu- } \\
\text { las maiores) }\end{array}$} & $\begin{array}{l}\text { Clastos arredondados e/ou angulosos, su- } \\
\text { bordinados em relação à matriz fina, e } \\
\text { dispersos aleatoriamente; formados a par- } \\
\text { tir dos mesmos processos geradores dos } \\
\text { paraconglomerados (são os depósitos } \\
\text { mais distais dos transportes de massa) }\end{array}$ \\
\hline \multirow[t]{2}{*}{ AREIAS } & \begin{tabular}{l|l|} 
AS & GROSSAS \\
\end{tabular} & (mais de $15 \%$ de areias médias e grossas) \\
\hline & FINAS & (mais de $50 \%$ de areias fina e muito fina) \\
\hline \multirow{2}{*}{ FINOS } & SILTES & \multirow{2}{*}{$\begin{array}{l}\text { Avaliação táctil-visual e segundo a clas } \\
\text { sificação de SHEPARD (1954). }\end{array}$} \\
\hline & ARGILAS & \\
\hline
\end{tabular}

par os depósitos cenozóicos em seis unidades principais: 1) Formação Sete Barras (Tsb); 2) Formação Pariqüera-Açu, subdividida em uma fácies fanglomerática (Tpaf), uma fácies fluvial meandrante (Tpam) e uma fácies lacustre (Tpal); 3) depósitos de cascalhos em nível superior de terraços $(T Q c s) ; 4)$ depósitos de cascalhos em nível intermediário de terraços (TQci); 5) depósitos colúvio-aluviais pliopleistocênicos (TQca); e 6) coberturas sedimentares quaternárias, estas subdivididas em aluviões, em várzeas e baixos terraços $(Q a)$, depósitos de tálus $(Q t)$, sedimentos indiferenciados de deposição mista $(Q i)$, sedimentos de cordões litorâneos pré-atuais $(\mathrm{Qm})$, depósitos de mangue (Qmg) e sedimentos de deposição praial $(Q p)$ (FIGURAS 1 e 2).

No presente estudo serão tratados somente os sedimentos anteriormente atribuídos à Formação Pariqüera-Açu (unidades 1 a 5 citadas anteriormente).

\section{TERMINOLOGIA}

No QUADRO 1 apresenta-se uma síntese da terminologia adotada para a classificação de cam- 
po dos sedimentos da área estudada. Esta classificação baseou-se não só nas características texturais dos depósitos, como também no arranjo interno e associações litológicas e nos indícios reconhecíveis de processos diagenéticos transformadores.

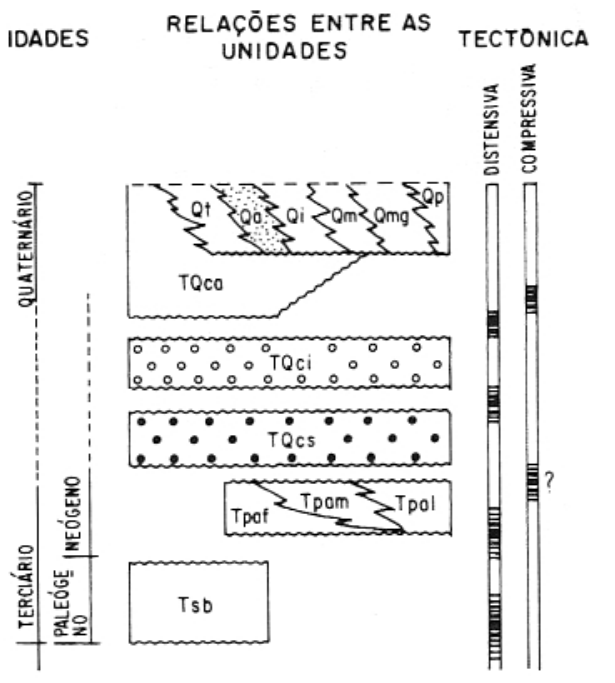

FIGURA 2 - Relações entre as unidades estratigráficas cenozóicas continentais e a tectônica na área do baixo Ribeira do Iguape. Ts $b$ : Formação Sete Barras; Tpaf: Formação Pariqüera-Açu fácies fanglomerática; Tpam: Formação PariqüeraAçu fácies fluvial meandrante; Tpal: Formação Pariqüera-Açu fácies lacustre; TQcs: cascalhos em nível topográfico superior de terraços; $T Q c i$ : cascalhos em nível intermediário de terraços; $T Q c a$ : depósitos colúvio-aluviais; Qt: depósitos de tálus; $Q a$ : aluviões; $Q i$ : sedimentos indiferenciados na planície costeira; $Q m$ : sedimentos de cordões litorâneos pré-atuais; $Q m g$ : sedimentos de mangues; $Q p$ : sedimentos de praias.

Assim, a classificação de campo reflete uma interpretação acerca dos processos formadores e contexto geológico dos sedimentos. Procurouse preservar a classificação de campo, ainda que os resultados das análises sedimentológicas não a confirmem na totalidade. Com este procedimento, procurou-se privilegiar uma terminologia que refletisse as condições da gênese dos sedimentos, em detrimento de maior precisão em relação à composição atual. Esta última é conseqüência tanto da gênese como dos processos diagenéticos e de alteração subseqüentes.

Nos trabalhos de campo, os sedimentos rudáceos $(50 \%$ ou mais de clastos maiores que $2 \mathrm{~mm}$, de acordo com RUST, 1983), algo consolidados, das unidades mais antigas da área estudada (formações Sete Barras e Pariqüera-Açu), foram classificados genericamente como con-
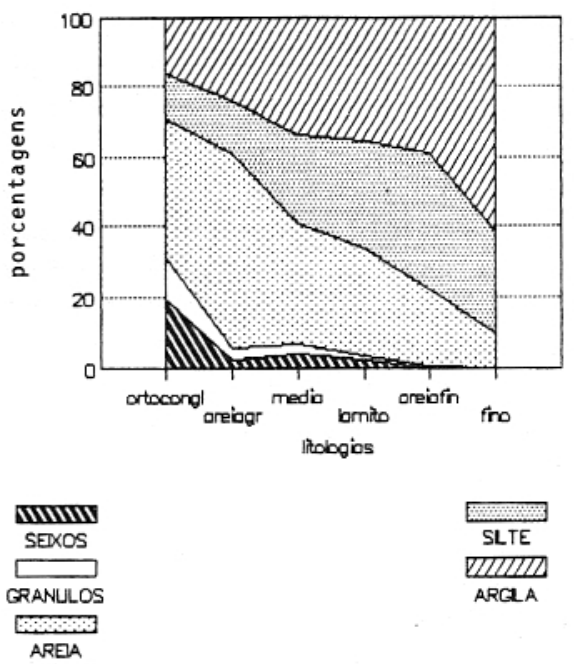

FIGURA 3 - Porcentagens médias das classes texturais por litologias.

glomerados, "um termo aplicável a cascalhos endurecidos", e brachas, estas referindo-se à "acumulação de fragmentos angulosos", (PETTIJOHN, 1975, p. 154).

Sempre que possível, os conglomerados foram distinguidos em ortoconglomerados e paraconglomerados, conforme segue:

Ortoconglomerados: depositados a partir da ação d'água com alta energia, originando sedimentos grossos com marcante arranjo interno dos clastos, estes predominantemente arredondados; a lama (silte + argila) presente na matriz não ultrapassa $15 \%$ em peso do sedimento, caracterizando o tipo "conglomerado suportado por clásticos”' (PETTIJOHN, op. cit., p. 164).

Paraconglomerados: depositados a partir de transporte de massa (corridas de lama, turbiditos e outras formas de fluxo de alta viscosidade ou fluxo denso), resultando em sedimentos grossos sem arranjo interno distinto, destacando-se matriz fina abundante, na qual os clastos maiores (arredondados e angulosos) apresentam-se dispersos, de forma aleatória; a proporção de finos (silte + argila) na matriz é abundante (mais de $15 \%$ ), caracterizando o arranjo tipo "diamictito" (PETTIJOHN, op. cit., p. 164), que alguns autores têm denominado "conglomerados suportados por matriz"' (RUST, 1983, p. 9).

O termo brecha foi empregado para alguns depósitos da Formação Pariqüera-Açu, encontrados junto às falhas ativas durante a sedimentação. Resultam aparentemente de uma combinação de processos tectônicos (fragmentação da rocha do embasamento) e sedimentares (curto transporte, misturando fragmentos e matriz, sem seleção), gerando cunhas clásticas rudáceas. No que diz res- 
peito à constituição, estas brechas assemelhamse aos paraconglomerados, distinguindo-se destes por apresentarem unicamente clastos angulosos.

O termo cascalho foi reservado para os depósitos rudáceos dos terraços fluviais da área estudada, mais novos que as formações Sete Barras e Pariqüera-Açu. Os cascalhos correspondem aos ortoconglomerados, distinguindo-se destes apenas por serem menos consolidados.

$\mathrm{O}$ termo lamito foi utilizado de forma indistinta para sedimentos das formações Sete Barras, Pariqüera-Açu e coberturas mais recentes, como as incluídas na unidade denominada "depósitos colúvio-aluviais”. Em geral, os lamitos apresentam abundante matriz fina (mais de $50 \%$ de silte+argila), mas sempre contendo proporção considerável (mais de 15\%) de areias e partículas maiores, dispersas aleatoriamente na matriz fina. Estes depósitos resultam dos mesmos processos de transporte de massa (ou fluxos densos) que originam os paraconglomerados, sendo que os lamitos distinguem-se pela granulação mais fina, com predominância da matriz (depósitos mais distais de corridas de lama).

$\mathrm{O}$ termo areia grossa foi utilizado para sedimentos com mais de $15 \%$ de areias média e grossa, contendo no máximo cerca de $5 \%$ de partículas maiores. As areias grossas são depósitos formados em regime de tração, sob ação d'água ainda com elevada energia (inferior àquela dos ortoconglomerados e cascalhos).

$\mathrm{O}$ termo areia fina foi utilizado para sedimentos constituídos principalmente de areias fina e muito fina (totalizando mais de $50 \%$ ), contendo proporção insignificante de partículas
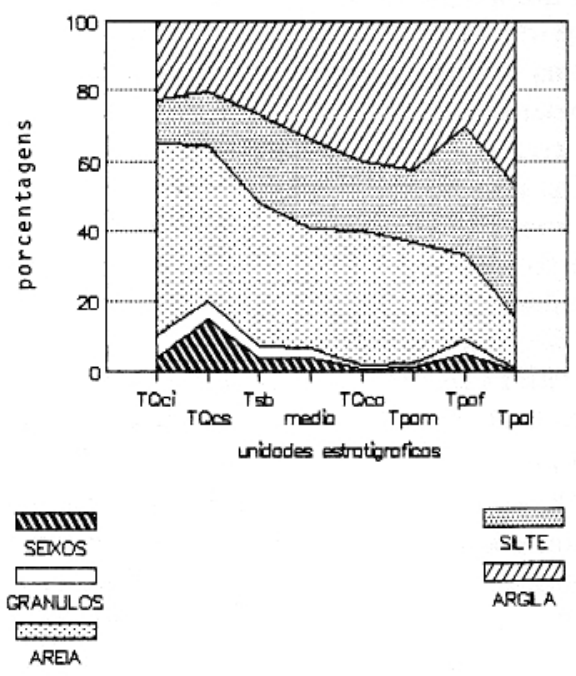

FIGURA 4 - Porcentagens médias das classes texturais por unidades estratigráficas.
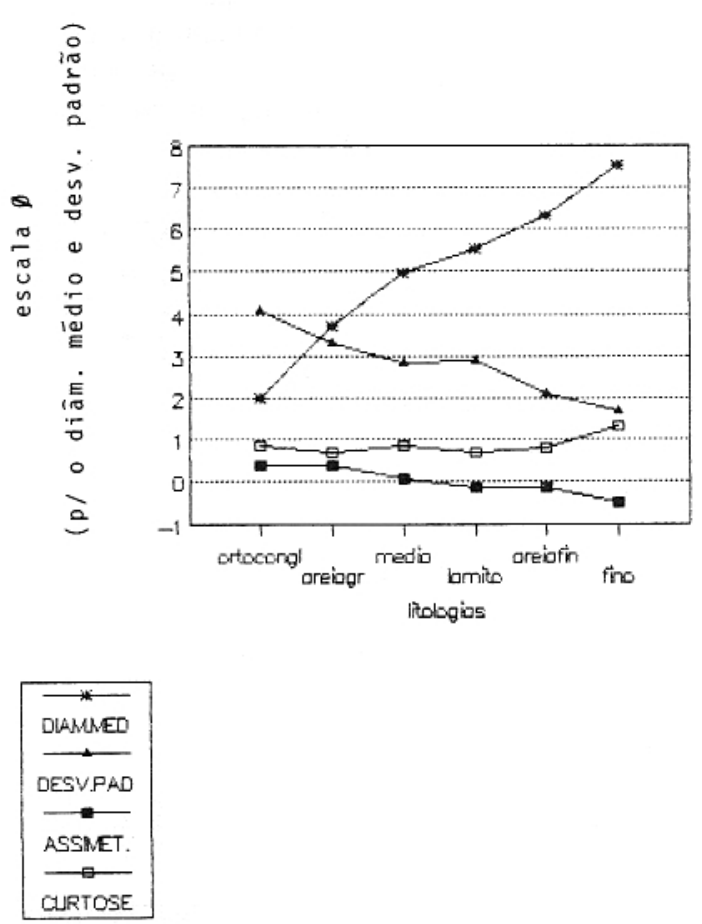

FIGURA 5 - Parâmetros estatísticos médios por litologias.
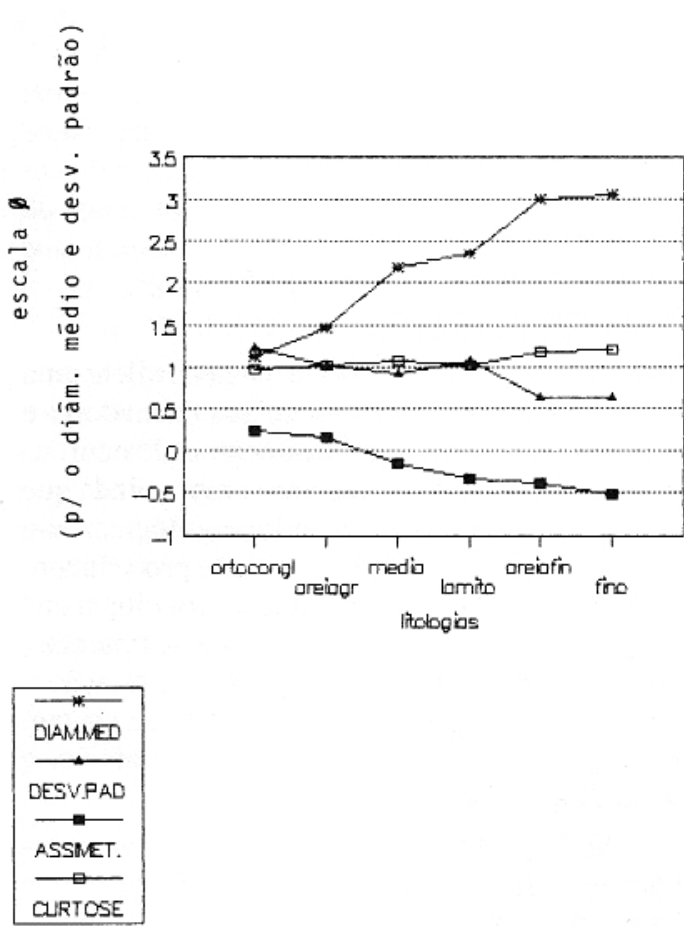

FIGURA 6 - Parâmetros estatísticos médios da fração areia por litologias. 

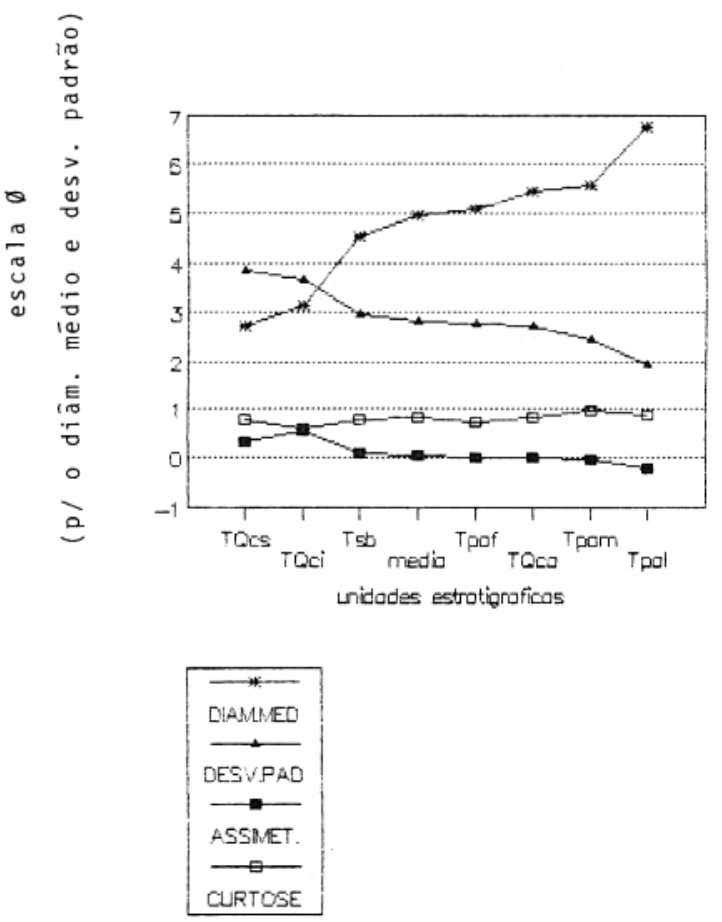

FIGURA 7 - Parâmetros estatísticos médios por unidades estratigráficas.
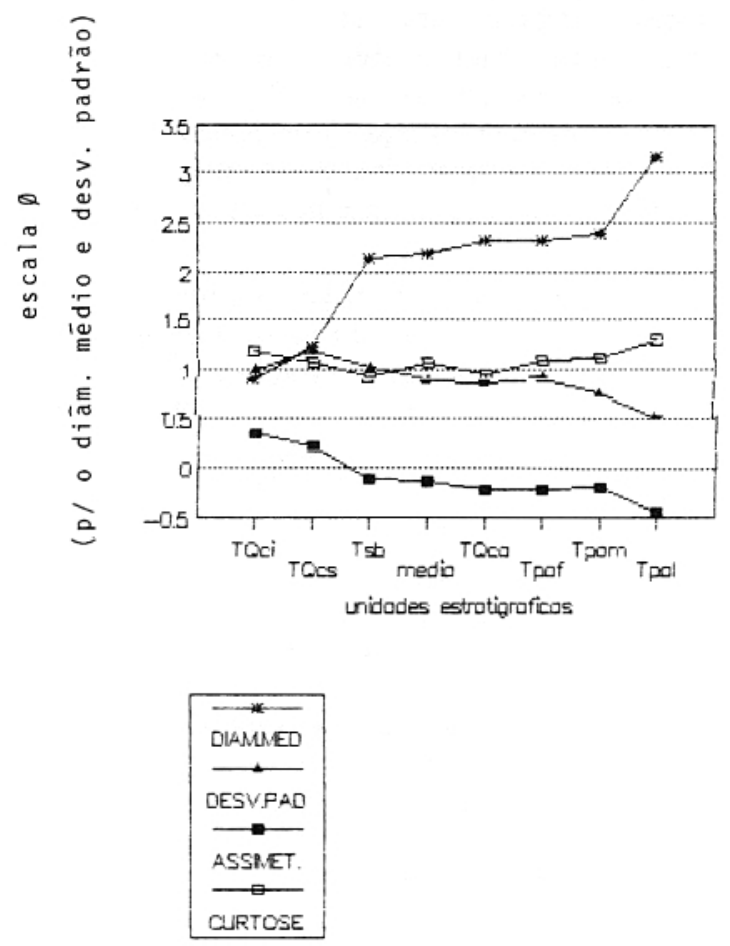

FIGURA 8 - Parâmetros estatísticos médios da fração areia por unidades estratigráficas.
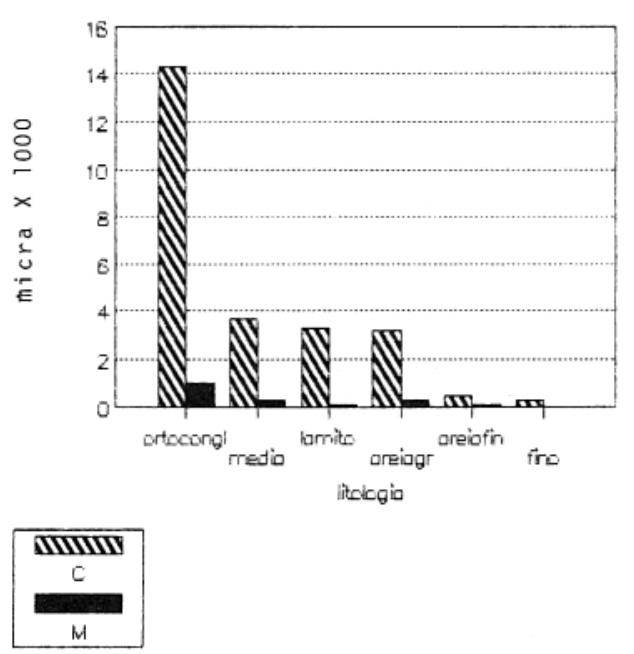

FIGURA 9 - Valores médios de C e M (micra $\mathrm{X}$ 1000) por litologias.

maiores. Trata-se, em parte, de depósitos formados ainda em regime de tração, sob ação d'água, mas em correntes com baixa energia e, em parte, de depósitos formados no limite tração/suspensão, sob regime misto (saltação).

$\mathrm{O}$ termo finos foi utilizado para sedimentos predominantemente siltosos e/ou argilosos, formados em regime misto tração/suspensão (saltação), ou em suspensão. Refletem condições de transbordamento e/ou rompimento de diques marginais, e de deposição em corpos d'água tranqüila. Os termos silte ou argila foram utilizados somente nas seções geológicas, com base nos resultados das análises granulométricas.

\section{ANÁLISES GRANULOMÉTRICAS}

Foram realizadas análises granulométricas em 106 amostras de sedimentos da Formação Pariqüera-Açu e depósitos relacionados. Estas análises, bem como as análises de minerais pesados e de argila, visaram dar maior suporte às interpretações estratigráficas, através da identificação dos processos geradores, paleoambientes e poleoclimas atuantes durante a sedimentação. Em vista deste objetivo, os resultados das análises foram avaliados somente quanto aos aspectos mais genéricos e abrangentes.

As amostras arenosas foram destorroadas manualmente e quarteadas até obtenção de duas porções representativas. Uma porção foi seca em estufa a $60^{\circ} \mathrm{C}$ por $48 \mathrm{~h}$, e pesada para obtenção do teor de umidade. Outra porção foi desagregada em meio aquoso, com o auxílio de agitador mecânico, e transferida para proveta onde o volume foi completado para $1.000 \mathrm{ml}$, após a adição de $1 \mathrm{~g}$ de pirofosfato de sódio como defloculante.

A suspensão assim obtida foi submetida a pipetagem, levando-se em conta a Lei de Stokes. Após a pipetagem, as amostras foram sub- 
metidas ao peneiramento, adotando-se a escala granulométrica de Wentworth (1922, apud SUGUIO, 1973).

Maiores detalhes das análises, com as porcentagens retidas simples e acumuladas por peneira, podem ser encontrados em IPT (1990).

Os resultados das análises granulométricas (classes texturais e parâmetros estatísticos, FOLK \& WARD, 1957) estão sintetizados nas FIGURAS 3 a 8, onde são apresentados valores médios. AS FIGURAS 9 a 11 mostram os valores médios dos parâmetros C e M (PASSEGA, 1957).

Na FIGURA 3 observa-se a distribuição dos valores das porcentagens em peso das classes texturais desde as litologias mais grossas (ortoconglomerados) até as mais finas.

Na FIGURA 4 observa-se a distribuição das classes texturais por unidade estratigráfica. As unidades com maior porcentagem das classes mais grossas (seixos + grânulos + areia) são os cascalhos dos níveis superior e intermediário de terraços (TQcs e TQci) e a Formação Sete Barras $(T s b)$, esta constituída em grande parte por depósitos imaturos de leques aluviais (lamitos, ortoconglomerados e areias grossas).

As unidades com maiores porcentagens das classes mais finas (silte + argila) são justamente os depósitos da Formação Pariqüera-Açu fácies lacustre (Tpal), fácies fanglomerática (Tpaf) e fácies fluvial meandrante (Tpam). Destaca-se, neste grupo, a presença da fácies fanglomerática (Tpaf), que apresenta expressiva porcentagem de seixos + grânulos em contraste com a alta porcentagem de silte + argila, o que reflete remanejamento fluvial incipiente dos depósitos imaturos de fluxos densos (lamitos) dos leques aluviais. A abundância de silte + argila nestes depósitos relativamente aos depósitos da Formação Sete Barras, também de leques aluviais, pode estar associada a fatores paleoclimáticos (clima mais úmido, com maior alteração e geração de finos na área-fonte, na época da sedimentação Pariqüera-Açu). Alguns estudos comparativos têm mostrado abundância de finos em depósitos de leques de climas úmidos, em relação aos de climas mais secos (KOCHEL \& JOHNSON, 1984).

Na FIGURA 5 estão representadas as médias dos valores dos parâmetros estatísticos de FOLK \& WARD (1957), considerando-se a distribuição granulométrica total, por litologias. Observa-se de modo geral que, à medida que diminui o diâmetro médio, melhora a seleção, que varia de "muito mal selecionado" para os ortoconglomerados até "pobremente selecionado" para os finos.
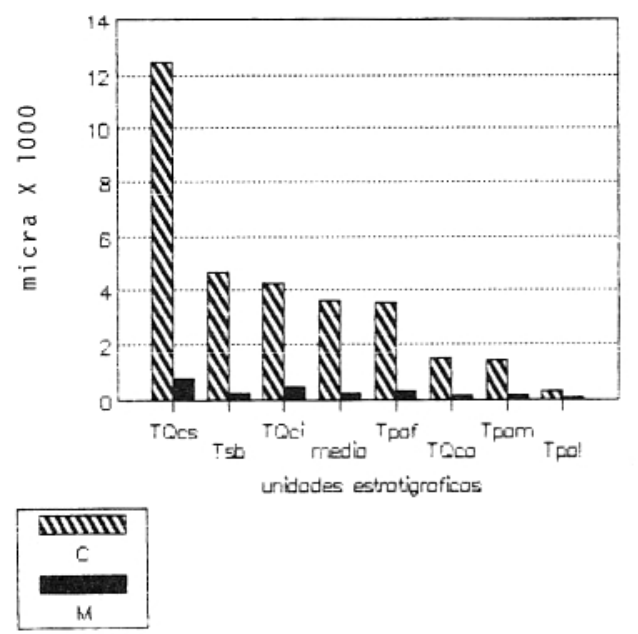

FIGURA 10 - Valores médios de $\mathrm{C}$ e $\mathrm{M}$ ( $m i$ cra $\mathrm{X} 1000$ ) por unidades estratigráficas.

A tendência da assimetria é variar de valores mais positivos para valores mais negativos com a diminuição do diâmetro médio. Os valores extremos indicam assimetria muito positiva para os ortoconglomerados e areias grossas, e assimetria muito negativa para os finos.

A tendência da curtose é variar de valores mais platicúrticos para valores mais leptocúrticos com a diminuição do diâmetro médio. Os valores extremos indicam curtose "muito platicúrtica" para as areias grossas, e curtose "leptocúrtica" para os finos. Os ortoconglomerados constituem exceção à tendência, com valor de curtose "platicúrtica", o que pode estar refletindo a adição de finos posteriormente à sedimentação.

As mesmas tendências gerais observadas para a distribuição total são verificadas também considerando-se somente a fração areia (FIGURA 6). A seleção varia de "pobremente selecionado" para os ortoconglomerados, melhorando até "moderadamente selecionado" para os finos.

Na FIGURA 7 estão apresentadas as médias dos valores dos parâmetros estatísticos da distribuição total por unidades estratigráficas. De modo geral, observam-se as mesmas tendências entre os parâmetros já constatadas para as litologias. Os depósitos do nível superior de terraços (TQcs) constituem a principal exceção. Trata-se de cascalhos (ou ortoconglomerados) mais permeáveis e mais antigos inclusive que os depósitos do nível intermediário de terraços (TQci), e com maiores possibilidades de alterações texturais posteriores à sedimentação.

Praticamente as mesmas tendências gerais são verificadas também considerando-se os parâmetros somente da fração areia (FIGURA 8). 

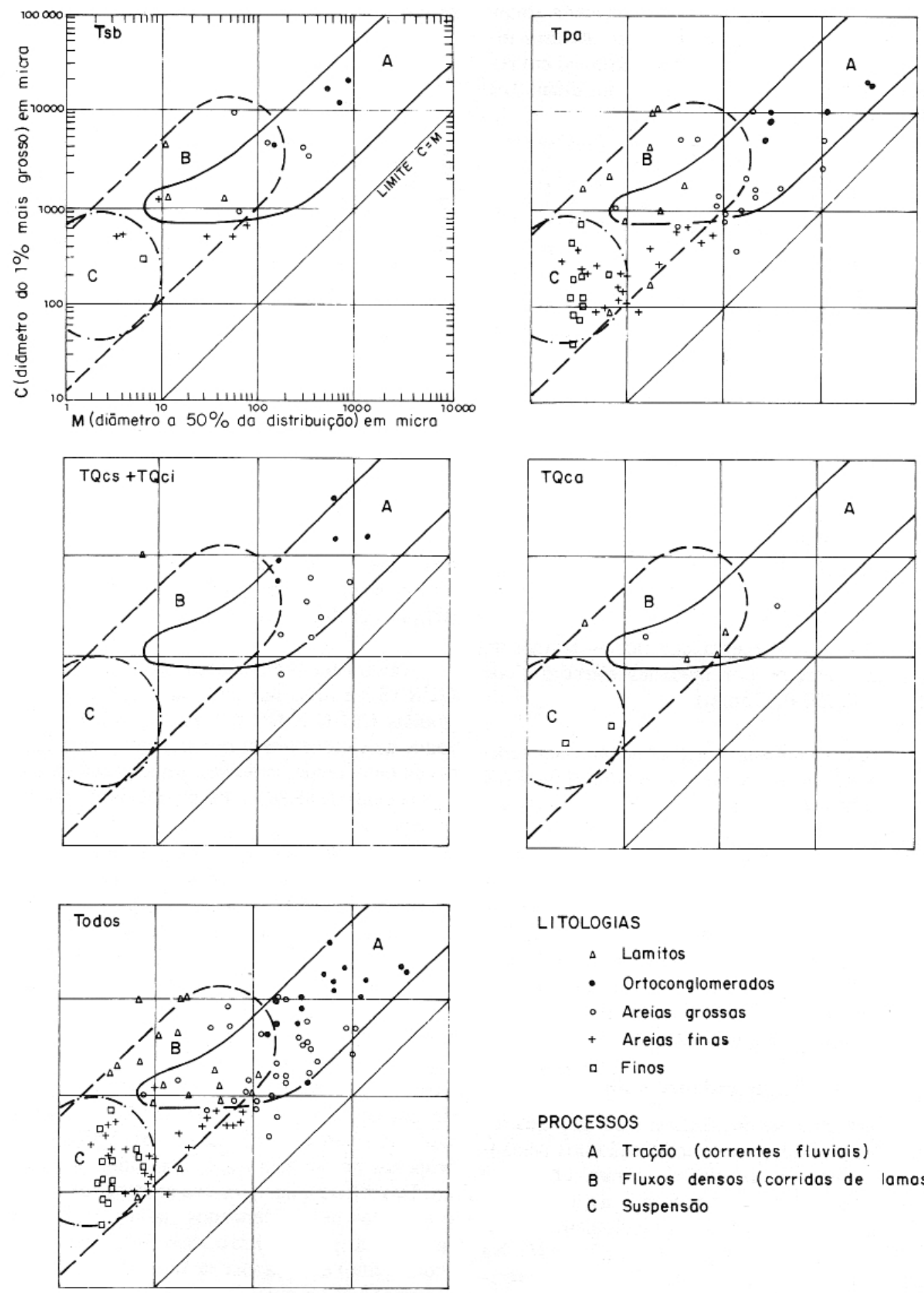

LITOLOGIAS

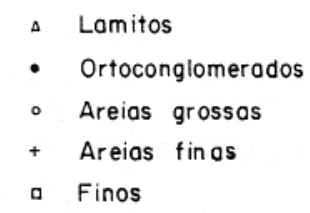

\section{PROCESSOS}
A Traçōo (correntes fluviais)
B Fluxos densos (corridas de lamas
C Suspensāo

FIGURA 11 - Diagramas CM dos sedimentos das diferentes unidades cenozóicas continentais do baixo Ribeira do Iguape (parâmetros segundo PASSEGA, 1957). 
Neste caso, observa-se que as amostras das unidades com diâmetros médios extremos (mais grossos ou mais finos) apresentam maiores índices de curtose (são mais leptocúrticas) em relação às amostras das unidades com diâmetros médios intermediários.

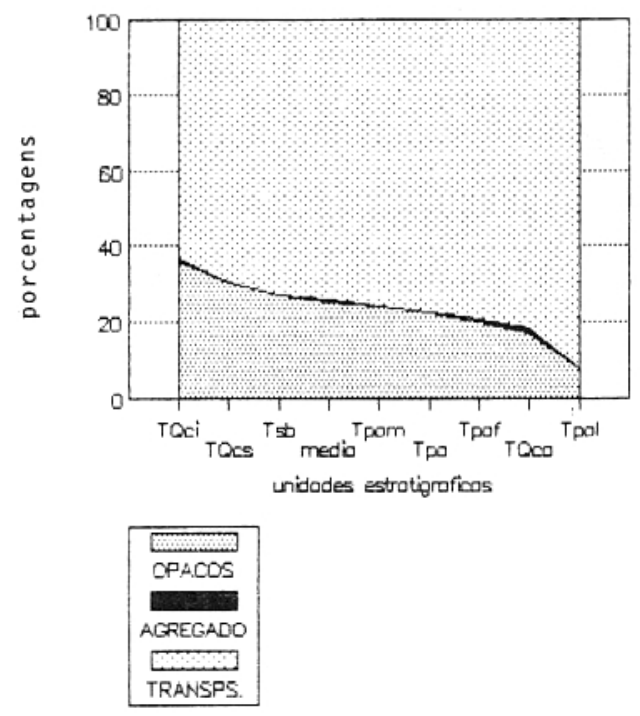

FIGURA 12 - Porcentagens médias de tipos de minerais pesados por unidades estratigráficas (fração 0,250-0,125mm).

$\mathrm{Na}$ extremidade correspondente aos sedimentos mais grossos nos gráficos das FIGURAS 4 e 7, juntamente com os cascalhos das unidades $T Q c s$ e $T Q c i$, encontram-se ainda os depósitos imaturos de leques aluviais da Formação Sete Barras $(T s b)$, à esquerda da média de valores de todas as amostras estudadas. Junto a estes, à direita da média, encontram-se os depósitos da fácies fanglomerática da Formação Pariqüera-Açu (Tpaf), seguidos dos depósitos colúvioaluviais (TQca) e fácies fluvial meandrante (Tpam) e lacustre (Tpal) da Formação Pariqüera-Açu.

\section{DIAGRAMAS CM}

Com o intuito de procurar distinguir os processos envolvidos na sedimentação dos depósitos continentais estudados, foram utilizados diagramas $\mathrm{CM}(\mathrm{C}=$ granulometria a $1 \%$ da distribuição mais grossa; $M=$ granulometria a $50 \%$ da distribuição, conforme PASSEGA, 1957). Na bibliografia preexistente, tais diagramas mostraram boa resolução tanto para sedimentos atuais (PASSEGA, 1957; BULL, 1962; KOCHEL \& JOHNSON, 1984) como para sedimentos antigos (PASSEGA, 1957 e 1964; BULL, 1972). Basicamente, os diagramas definem empiricamente padrões de distribuição dos valores $\mathrm{CM}$ que correspondem aos processos atuantes durante a sedimentação: tração (correntes fluviais); sus- pensão (águas calmas); fluxos densos (corridas de lama ou correntes de turbidez).

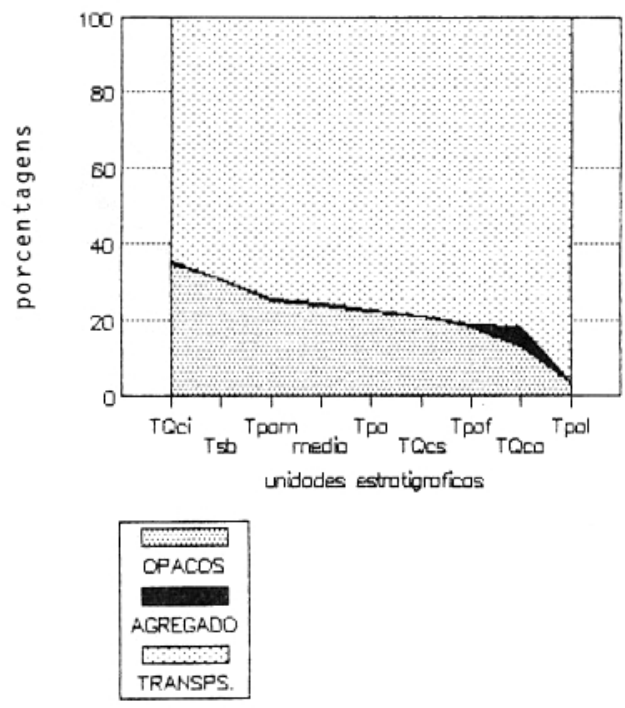

FIGURA 13 - Porcentagens médias de tipos de minerais pesados por unidades estratigráficas (fração 0,125-0,062mm).

Tanto para as análises granulométricas (FIGURAS 3 a 10) como para a elaboração dos diagramas CM (FIGURA 11), os ortoconglomerados e os cascalhos foram considerados indistintamente, tendo em vista a semelhança da litologia desses depósitos e dos processos envolvidos na sua gênese.

As distribuições de valores médios de $\mathrm{C}$ e M por litologias (FIGURA 9) e por unidades estratigráficas (FIGURA 10) seguem de modo geral a variação do diâmetro médio (FIGURAS 5 e 7). Entre as litologias, os lamitos constituem uma exceção, com altos valores de $\mathrm{C}$ em relação aos valores de $\mathrm{M}$, reflexo da natureza e constituição desses depósitos (fluxos densos, resultando em depósitos texturalmente muito imaturos). Entre as unidades estratigráficas, destaca-se o deslocamento dos depósitos colúvioaluviais (TQca) em direção à extremidade correspondente aos depósitos mais finos no gráfico. Isto reflete a inexpressiva presença de seixos e grânulos nestes depósitos, talvez em conseqüência do principal processo formador (coluvionamento) e clima vigente durante a deposição (comparável ao atual).

Nos diagramas CM (FIGURA 11), os padrões obtidos para os sedimentos da Formação Pariqüera-Açu e depósitos relacionados são compatíveis com os padrões da Bibliografia sobre processos fluviais, com algumas alterações. Parte destas alterações, como o acréscimo no valor da razão $\mathrm{C} / \mathrm{M}$ em relação aos estudos de BULL 
TABELA 1 - Composição mineralógica dos minerais opacos pesados de amostras de sedimentos cenozóicos do baixo Ribeira do Iguape, obtida através de difratometria de raios-X (os valores indicados expressam a porcentagem relativa dos minerais ilmenita $=$ ILM, pseudo-rutilo = PSR, rutilo = RUT e hematita $=$ HEM nas amostras analisadas).

UNIDADE AMOSTRA ILM PSR RUT HEM

\begin{tabular}{|c|c|c|c|c|c|}
\hline \multirow{4}{*}{ Tsb } & SA-641A & 100 & - & - & - \\
\hline & SA-641C & 60 & 40 & - & - \\
\hline & RE-472E & 65 & 35 & - & - \\
\hline & RE-463H & 60 & 40 & - & - \\
\hline \multirow{4}{*}{ Tpaf } & PA-16B & 40 & 60 & - & - \\
\hline & PA-16A & 60 & 40 & - & - \\
\hline & PA-81G & - & 50 & 50 & - \\
\hline & PA-77D & - & 100 & - & - \\
\hline \multirow{7}{*}{ Tpam } & PA-61B & 40 & 60 & - & - \\
\hline & PA-61A & 40 & 60 & - & - \\
\hline & PA-144B & 60 & 40 & - & - \\
\hline & RE-356B & 40 & 60 & - & - \\
\hline & JU-445I & 50 & 50 & - & - \\
\hline & JU-490C & 40 & 40 & 20 & - \\
\hline & $\mathrm{JU}-445 \mathrm{~A}$ & 50 & 50 & - & - \\
\hline Tpal & PA-714B & 70 & 30 & - & - \\
\hline \multirow[t]{2}{*}{ TQcs } & JA-654A & 60 & 40 & - & - \\
\hline & JA-34C & 90 & 10 & - & - \\
\hline \multirow{5}{*}{ TQci } & RE-539B & 30 & 70 & - & - \\
\hline & JA-658A & 80 & 20 & - & - \\
\hline & PA-01D & 50 & 45 & 5 & - \\
\hline & RE-222A & 70 & 30 & - & - \\
\hline & PA-01A & 60 & 20 & 10 & 10 \\
\hline TQca & JU-417B & 55 & 35 & 10 & - \\
\hline
\end{tabular}

(1962), pode ser atribuída à adição de finos nos depósitos do baixo Ribeira posteriormente à sedimentação por influência da diagênese e alteração intempérica.

$\mathrm{O}$ diagrama para todas as amostras permite definir três campos principais: um campo mais característico de processos de tração (contendo as amostras de ortoconglomerados e areias grossas); um campo de processos de fluxos densos (no caso, contendo as amostras de lamitos de corridas de lamas); e um campo mais característico de processos de suspensão (contendo as amostras de sedimentos finos, sejam lacustres, sejam de transbordamento em planície de inundação). As amostras de areias finas distribuem-se entre os campos relativos à tração e suspensão.
O diagrama para a Formação Sete Barras, ainda que o número de amostras não seja grande, reflete a presença de depósitos formados pelos três tipos de processos principais, o que seria compatível com o modelo de leques aluviais gradando para lago em depressão tectônica, admitido para esta unidade.

O diagrama para a Formação Pariqüera-Açu evidencia a ocorrência de depósitos atribuíveis aos três processos principais. Neste caso, as características dos depósitos levam a interpretar um modelo de gradação lateral de leques aluviais para planície fluvial meandrante e lago.

Diversamente, o diagrama para os depósitos dos níveis superior e intermediário de terraços com cascalhos (tratados em conjunto) indica essencialmente processo de tração, em correntes fluviais de alta energia. Tal característica seria compatível com sistemas fluviais entrelaçados (braided).

O diagrama para os depósitos colúvioaluviais, à semelhança do que se observa para a Formação Sete Barras, também sugere a presença dos três processos principais. A interpretação mais plausível, neste caso, parece ser a de depósitos coluviais (fluxos densos) parcialmente remanejados pelas correntes fluviais, estas sujeitas a transbordamentos ocasionais.

\section{MINERAIS PESADOS}

Com o material retido nas peneiras $0,125 \mathrm{~mm}$ e $0,062 \mathrm{~mm}$ durante as análises granulométricas, foram montadas lâminas de grãos de minerais pesados após separação da fração "leves" por meio de bromofórmio ( $d=2,89$ $\mathrm{g} / \mathrm{cm}^{3}$ ), e da fração magnética, por meio do ímã de mão e dos atraídos ao eletroímã Frantz a 0,4A. A identificação dos minerais pesados nãomagnéticos transparentes foi efetuada ao microscópio petrográfico de luz transmitida. A identificação dos minerais pesados opacos das amostras onde estes são mais abundantes foi realizada através de difratometria de raios-X, sobre a fração obtida pela separação isodinâmica.

As porcentagens dos grãos contados estão separadas em três grupos: opacos, agregados e transparentes. As porcentagens dos minerais pesados transparentes não-micáceos estão recalculadas para $100 \%$, para permitir o cálculo do índice ZTR (índice de maturidade, igual à soma das porcentagens de zircão + turmalina + rutilo, segundo HUBERT, 1962), e comparações entre os minerais ultra-estáveis (ZTR), estáveis (andaluzita, cianita, estaurolita, monazita, sillimanita e topázio) e instáveis (epídoto e granada, incluindo neste grupo os semi-estáveis espinélio e titanita). 
As FIGURAS 12 e 13 mostram as porcentagens relativas de opacos, agregados e transparentes, nas duas frações, por unidades estratigráficas. Nota-se estreita relação destes gráficos com aqueles que expressam a granulometria média das unidades estratigráficas (FIGURAS 4 e 7), revelando-se correlação entre os depósitos mais grossos e mal selecionados com os depósitos portadores de maiores porcentagens de opacos, aparentemente como reflexo da equivalência hidráulica.

Na TABELA 1 estão apresentadas as proporções relativas dos minerais opacos (separados pelo eletroímã a $0,4 \mathrm{~A}$ ) de algumas amostras, estimadas a partir das áreas dos picos principais obtidos em difratogramas de raios-X. Em todas as unidades aparecem ilmenita e pseudo-rutilo, ocorrendo ainda rutilo (em associação com os demais minerais) em várias unidades e hematita, esta em uma amostra dos cascalhos do nível intermediário de terraços (TQci).

De maneira geral, nota-se abundância relativa da ilmenita nas amostras da Formação Sete Barras (Tsb), e discreta abundância relativa deste mineral nas amostras dos cascalhos dos dois níveis de terraços (TQcs) e (TQci). Inversamente, nota-se abundância relativa do pseudo-rutilo nas amostras da fácies fanglomerática da Formação Pariqüera-Açu (Tpaf).

O pseudo-rutilo é considerado como um estágio intermediário dos processos de oxidação e lixiviação da ilmenita, cujo produto final levaria à produção de rutilo (TEUFER \& TEMPLE, 1966; TEMPLE, 1966; GREY \& REID, 1975). Enquanto estes autores consideram que a oxidação e a lixiviação da ilmenita desenvolvem-se em estreita relação com o nível do lençol freático, outros consideram que o fator climático e a alteração das rochas na área-fonte seriam os principais determinantes da alteração da ilmenita e enriquecimento relativo de pseudorutilo e rutilo, com conseqüente enriquecimento de titânio (PUFFER \& COUSMINER, 1982).

Tendo em vista esta última corrente de idéias, é possível que as constatações acima, baseadas nos dados da TABELA 1 , estejam refletindo as condições climáticas vigentes durante a sedimentação, que teriam propiciado menor transformação da ilmenita (clima mais seco) durante a deposição da Formação Sete Barras e dos cascalhos dos níveis de terraços, e maior transformação da ilmenita (clima mais quente e úmido) durante a sedimentação da Formação Pariqüera-Açu.

Já os agregados, que refletem minerais instáveis e estáveis em diferentes estágios de alteração, aparecem quase que exclusivamente nos depósitos colúvio-aluviais. Tal fato parece traduzir alguns fatores associados à gênese destes depósitos: pequeno transporte (coluvionamento), idade relativamente nova e origem a partir de regolito gerado em condições climáticas semelhantes às atuais.

A FIGURA 14 mostra as porcentagens relativas de todos os minerais pesados transparentes identificados, nas frações mais grossa e mais fina. Constata-se maior abundância de turmalina, estaurolita, andaluzita e zircão, minerais comuns às rochas do embasamento cristalino da área. Turmalina e granada ocorrem em maior abundância na fração mais grossa, enquanto zircão, estaurolita, monazita e epídoto aparecem principalmente na fração mais fina.

AS FIGURAS 15 e 16 mostram os valores médios (para todas as litologias) do índice ZTR e as somas das porcentagens dos minerais estáveis e instáveis, por unidades estratigráficas, nas duas frações. Nos dois casos, os menores valores do índice ZTR correspondem aos depósitos dos níveis superior e intermediário de terraços (TQcs e TQci) e da fácies fanglomerática da Formação Pariqüera-Açu (Tpaf). Para esta última, o baixo valor do índice ZTR parece refletir a imaturidade dos sedimentos, formados em leques aluviais pouco remanejados pelas correntes fluviais. Já para os depósitos dos níveis de terraços, associados a uma drenagem ancestral dos principais rios atuais da área, os baixos valores relativos de ZTR devem ser atribuídos a condições paleoclimáticas que favoreceram a preservação de minerais menos estáveis.

No outro extremo, com altos valores relativos do índice ZTR, aparecem a Formação Sete Barras (Tsb), os depósitos colúvio-aluviais (TQca) e as fácies lacustre e fluvial meandrante da Formação Pariqüera-Açu (Tpal e Tpam). Para o caso da Formação Sete Barras, esta aparente maturidade indicada pelos minerais pesados transparentes contrasta com outros indicadores, como a presença de abundantes clastos de litologias e minerais instáveis, e a imaturidade textural destes depósitos. Na verdade, o alto valor relativo do índice ZTR deve-se, no caso, a altas porcentagens de turmalina nas amostras analisadas, o que deve refletir sobretudo a área-fonte dos depósitos da Formação Sete Barras, situados sobre a Zona de Cisalhamento de Cubatão, sujeita a intenso processo de turmalinização e formação de turmalinitos.

Os altos valores do índice ZTR para os depósitos colúvio-aluviais devem ser atribuídos a fatores paleoclimáticos, enquanto que, para as fácies lacustre e fluvial meandrante da Formação Pariqüera-Açu, o elevado ZTR parece cor- 

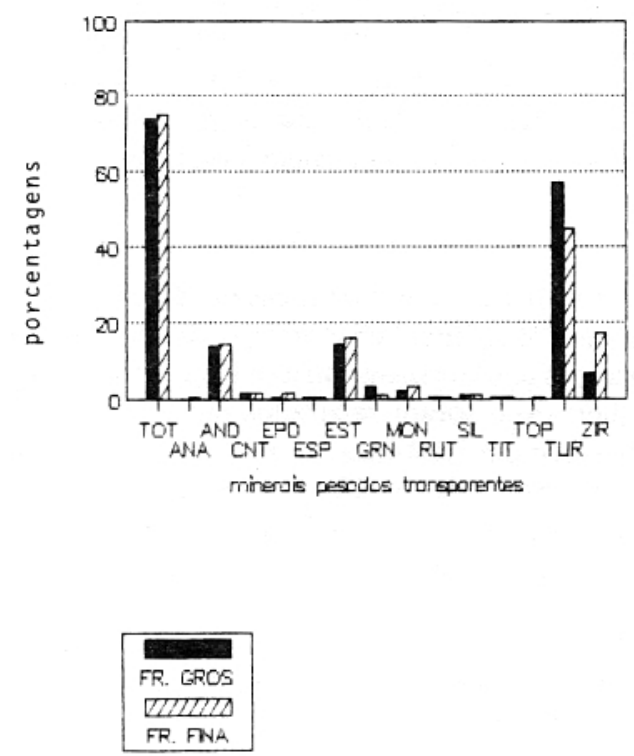

FIGURA 14 - Porcentagens médias dos principais minerais pesados transparentes segundo as duas frações estudadas.
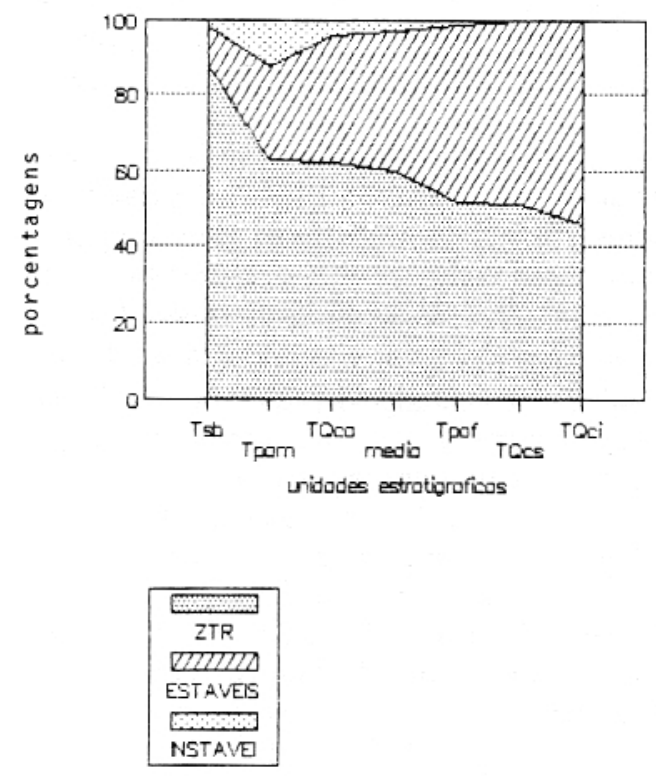

FIGURA 15 - Porcentagem média de tipos de minerais pesados transparentes por unidades estratigráficas (fração 0,250-0,125mm).
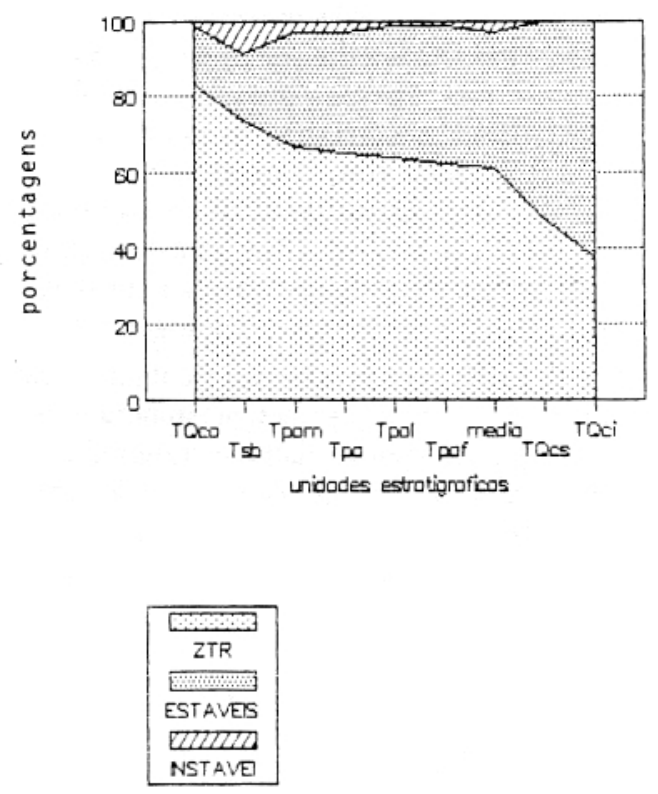

FIGURA 16 - Porcentagem média de tipos de minerais pesados transparentes por unidades estratigráficas (fração 0,125-0,062 mm).
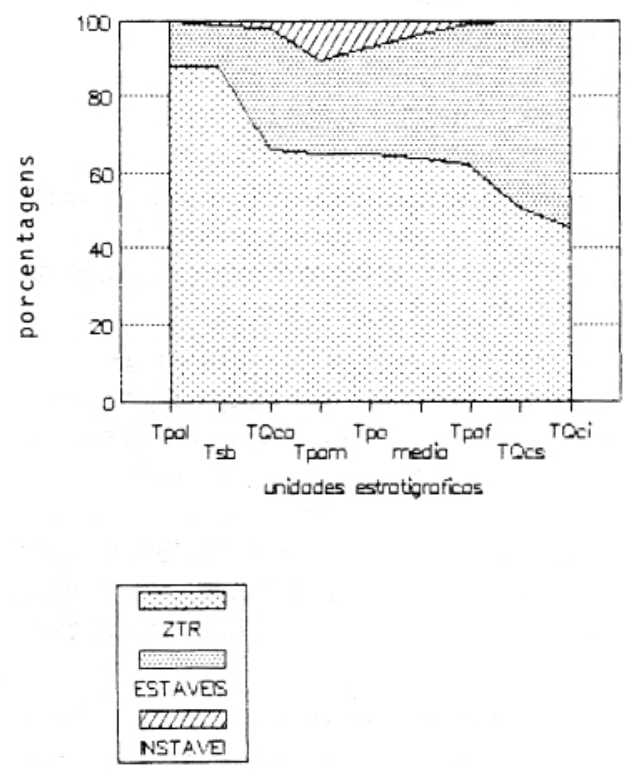

FIGURA 17 - Porcentagem média de tipos de minerais pesados transparentes nos ortoconglomerados e areias grossas por unidades estratigráficas (fração $0,250-0,125 \mathrm{~mm}$ ). 
responder ao maior remanejamento e maturidade dos depósitos.

As FIGURAS 17 e 18 mostram os valores médios do índice ZTR e das somas das porcentagens dos minerais estáveis e instáveis por unidades estratigráficas, nas duas frações, somente para as amostras das litologias, ortoconglomerados e areias grossas (que são as litologias constituintes dos cascalhos TQcs e TQci). Observam-se os mesmos padrões relativos de distribuição constatados para as médias de todas as litologias.

Nas FIGURAS 19 e 20 apresentam-se as porcentagens médias dos principais minerais pesados transparentes por unidades estratigráficas, nas duas frações. Estas figuras, que são detalhamentos das FIGURAS 15 e 16, permitem apreciar com maior precisão a composição mineralógica dos pesados transparentes.

\section{MINERAIS DE ARGILA}

$\mathrm{Na}$ fase de pipetagem das amostras analisadas para granulometria foram colhidos, para cada amostra, volumes da suspensão contendo a fração argila (menor que quatro micra). Após centrifugação, esta argila foi aplicada com movimentos paralelos de espátula sobre lâminas de vidro, de modo a propiciar a orientação das partículas. As análises mineralógicas da fração argila foram efetuadas por difratometria de raios-X sobre as amostras no estado natural, com adição de etilenoglicol e após aquecimento a $500^{\circ} \mathrm{C}$ por 2 horas. Após a interpretação dos difratogramas, efetuouse uma semiquantificação dos minerais de argila com base na proporcionalidade das áreas dos picos principais nos difratogramas.

A FIGURA 21 mostra a porcentagem relativa dos três principais tipos de minerais de argila identificados (grupo da caulinita, grupo da illita e grupo das esmectitas).

O principal resultado das análises de minerais de argila é a constatação de que o grupo das esmectitas aparece exclusivamente em depósitos da Formação Sete Barras. De fato, a ocorrência deste mineral em amostras da Formação Pariqüera-Açu já fora indicada por FRANZINELLI (1970) em afloramentos atribuídos, no presente estudo, a sedimentos da Formação Sete Barras.

A presença de mineral de argila do grupo das esmectitas nos depósitos da Formação Sete Barras é interpretada como um indicador paleoclimático, à semelhança do que tem sido proposto para os sedimentos da Formação Tremembé na Bacia de Taubaté (SUGUIO, 1969) e para depósitos paleogênicos das bacias de Resende, Taubaté e Curitiba (COIMBRA \& RICCOMINI,
1985), onde a associação de camadas argilosas contendo este mineral com níveis de calcrete tem sido interpretada como indicação de climas semiáridos. RICCOMINI (1989) e BRANDT NETO et al. (1990) também admitiram clima semi-árido durante o início da sedimentação nas bacias de São Paulo, Taubaté, Resende e Volta Redonda.

\section{CONCLUSÕES}

Com base nas características litológicas e relações estratigráficas observadas, os depósitos cenozóicos anteriormente atribuídos à Formação Pariqüera-Açu foram separados em cinco unidades principais distintas: Formação Sete Barras $(T s b)$; Formação Pariqüera-Açu, compreendendo uma fácies fanglomerática de leques aluviais coalescentes (Tpaf), uma fácies de planície fluvial meandrante (Tpam), e uma facies lacustre (Tpal); depósitos de cascalhos em nível superior de terraços, situados em posição topográfica mais elevada (TQcs); depósitos de cascalhos em nível intermediário de terraços, mais baixos em relação aos anteriores (TQci); e depósitos colúvio-aluviais (TQca).

A Formação Sete Barras (Tsb) constitui o preenchimento sedimentar de uma depressão tectônica alongada na direção N5OE, denominada Gráben de Sete Barras. Os depósitos, com espessura máxima estimada por sondagens elétricas verticais entre 130 e 200 m, são interpretados como originados por leques aluviais coalescentes, gradando para um lago no interior da depressão tectônica. Os sedimentos resultam, portanto, de processos de fluxos densos, tração e suspensão. Representam o mais antigo depósito associado à atividade tectônica cenozóica na área estudada (Eoceno-Oligoceno?). A abundância de clastos e minerais instáveis na Formação Sete Barras, bem como de argilas esmectíticas, sugere clima semi-árido durante a deposição.

Na acepção adotada aqui, a denominação Pariqüera-Açu abrange depósitos provavelmente eomiocênicos que ocorrem sobretudo na área da cidade que lhes empresta o nome, estendendose ao vale do Rio Jacupiranga e às vizinhanças da cidade de Registro. Compreende depósitos fanglomeráticos de leques aluviais associados a falhas sinsedimentares (Tpaf), gradando lateralmente para depósitos de planície fluvial meandrante (Tpam) e de lagos (Tpal). Esta variação faciológica encontra nítida expressão no diagrama CM, indicando também neste caso a presença de processso de fluxos densos, tração e suspensão. A espessura máxima é de cerca de 15 metros em afloramentos, podendo localmente atingir espessuras maiores, conforme sugerem algumas das sondagens elétricas verticais realizadas. 

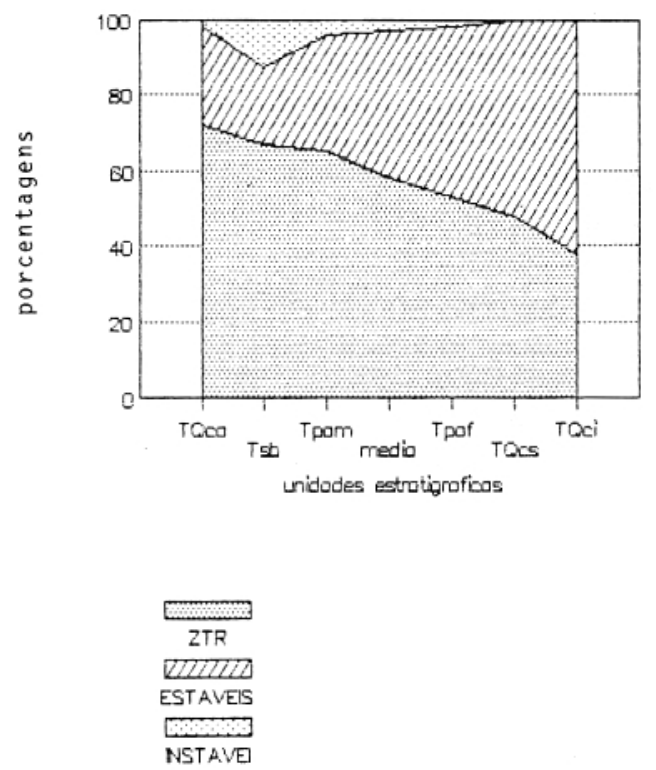

FIGURA 18 - Porcentagem média de tipos de minerais pesados transparentes nos ortoconglomerados e areias grossas por unidades estratigráficas (fração 0,125-0,062mm).
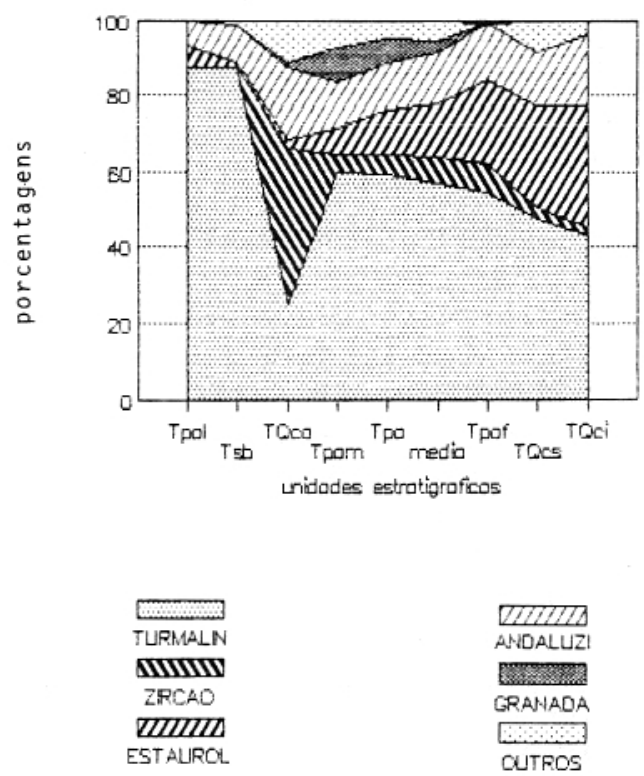

FIGURA 19 - Porcentagens médias de minerais pesados transparentes mais comuns por unidades estratigráficas (fração $0,250-0,125 \mathrm{~mm}$ ).

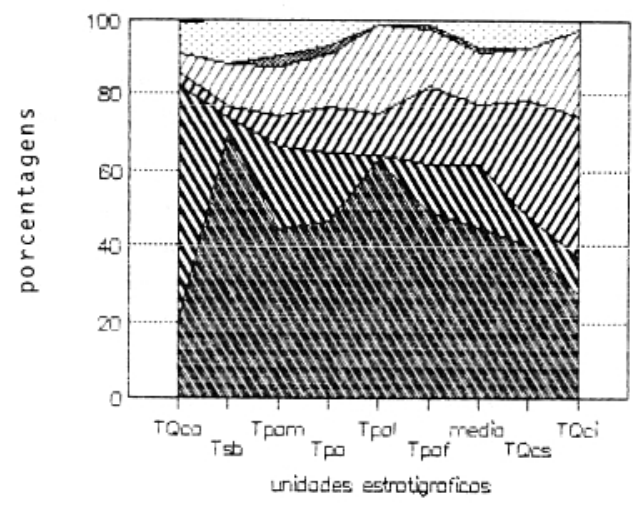

\begin{tabular}{|c|c|}
\hline 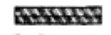 & CZEUDJ \\
\hline TLPMALLN & ANQALUZ! \\
\hline SIIIIIIV & 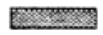 \\
\hline ZRCAO & GRANAC \\
\hline ZWWDL & 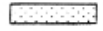 \\
\hline ESTALROL & QUTROS \\
\hline
\end{tabular}

FIGURA 20 - Porcentagens médias de minerais pesados transparentes mais comuns por unidades estratigráficas (fração 0,125-0,062mm).
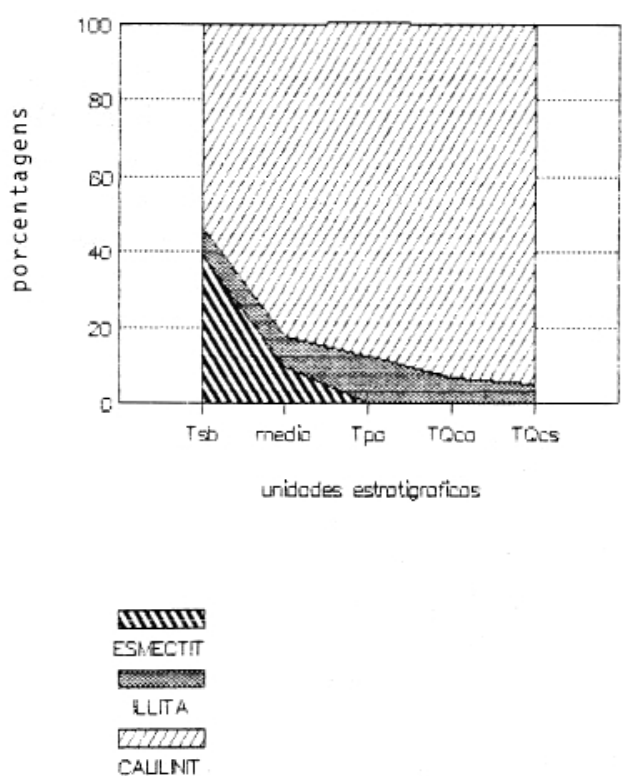

FIGURA 21 - Porcentagens médias de tipos de minerais de argila por unidades estratigráficas. 
O clima vigente durante a deposição da Formação Pariqüera-Açu aparentemente era úmido, como sugerem a relativa escassez de clastos e minerais instáveis, a presença dominante de argilas caoliníticas, a relativa abundância de pseudo-rutilo e o desenvolvimento de sistemas fluvial meandrante e lacustre.

O nível superior de terraços com cascalhos aparece como uma superfície embutida e erosivamente desfeita, principalmente ao longo dos vales dos rios Ribeira e Jacupiranga. Os depósitos associados a este nível de terraços ("os cascalhos") (TQcs) atingem no máximo pouco menos de uma dezena de metros de espessura, e são constituídos de rudáceos oligomíticos associados a areias feldspáticas. Os minerais pesados transparentes revelam os menores valores do índice ZTR entre as unidades estudadas, indicando relativa imaturidade mineralógica para a fração areia. Estes sedimentos, bem como a construção do nível de terraços, são atribuídos a uma fase de vigência de clima seco, com desenvolvimento de sistema fluvial entrelaçado, predominando o processo de tração.
Os testemunhos do nível intermediário de terraços com cascalhos encontram-se embutidos erosivamente, e em cotas mais baixas em relação aos testemunhos do nível superior, indicando que este último é mais antigo. A constituição destes cascalhos (TQci) também é muito semelhante àquela dos depósitos do nível superior, o que sugere gênese associada aos mesmos fatores paleoclimáticos (clima seco) e deposicionais (sistema fluvial entrelaçado).

Os depósitos colúvio-aluviais (TQca) abrangem as coberturas localizadas em várias situações topográficas, podendo ser relacionados à evolução das encostas em tempos não remotos, quando o paleo-relevo não era substancialmente diferente do relevo atual. Recobrem, em alguns locais, os cascalhos do nível intermediário de terraços, sendo, portanto, mais novos. Aparentemente são depósitos correlativos de oscilações climáticas pleistocênicas, determinantes da instabilização temporária do manto de regolito. Este teria sido formado previamente, sob condições de clima úmido, o que é sugerido, em termos da mineralogia, pela abundância de agregados e elevado índice ZTR.

\section{REFERÊNCIAS BIBLIOGRÁFICAS}

BIGARELLA, J.J. \& MOUSINHO, M.R. 1965 Contribuição ao estudo da Formação Pariqüera-Açu (Estado de São Paulo), Boletim Paranaense de Geografia, (16/17):17-41.

BRANDT NETO, M.; RICCOMINI, C.; COIMBRA, A.M.; MATOS, S.L.F. de. 1990 Argilominerais da Bacia de Taubaté, SP. In: JORNADAS CIENTÍFICAS DO INSTITUTO DE GEOCIÊNCIAS - USP, São Paulo, 1990. Boletim Especial - Trabalhos Apresentados... São Paulo, Instituto de Geociências da USP, p.16-20.

BULL, W.B. 1962 Relation of textural (CM) patterns to depositional environment of alluvial-fan deposits. Journal of Sedimentary Petrology, 32(2):211-216.

1972 Recognition of alluvial-fan deposits in the stratigraphic record, In: HAMBLIN, W.K. \& RIGBY, J.K. (Eds.), Recognition of ancient sedimentary environments. Tulsa, Society of Economic Paleontologists Mineralogists. p.63-83. (Special Publication, 16)

COIMBRA, A.M. \& RICCOMINI, C. 1985 Considerações paleoambientais sobre as ocorrências de caliche nas bacias de Curitiba (PR), Taubaté (SP) e Resende (RJ). Anais da Academia Brasileira de Ciências, Rio de Janeiro, 54(4):517-518.
FOLK, R.L. \& WARD, W.C. 1957 Brazos river bar: a study in the significance of grain size parameters. Journal of Sedimentary Petrology, 27:3-26.

FRANZINELLI, E. 1970 Estudo sedimentológico da Formação Pariqüera-Açu (Estado de São Paulo). São Paulo. 56p. (Dissertação de Mestrado, Instituto de Geociências-USP).

GREY, I.A. \& REID, A.F. 1975 The structure of pseudorutile and its role in the natural alteration of ilmenite. American Mineralogist, 60(9/10):179-181.

HUBERT, J.F. 1962 A zircon-tourmaline-rutile maturity index and the interdependence of the composition of heavy minerals assemblages with the gross composition and texture of sandstones. Journal of Sedimentary Petrology, 32(3):440-450.

INSTITUTO DE PESQUISAS TECNOLÓGICAS DO ESTADO DE SÃO PAULO IPT. 1990 A Formação Pariqüera-Açu: relações entre sedimentação, tectônica e geomorfogênese; complementação. (Relatório IPT 28.186)

KOCHEL, R.C. \& JOHNSON, R.A. 1984 Geomorphology and sedimentology of humidtemperate alluvial fans, Central Virginia. In: KOSTER. E.H. \& STEEL, R.J. (Eds.), Sedimentology of gravels and conglomerates. 
Calgary, Canadian Soc. Petr. Geol. p. 109-122 (Memoir 10).

MELO, M.S. de. 1990 A Formação PariqüeraAçu e depósitos relacionados: sedimentação, tectônica e geomorfogênese. São Paulo. 211 p. (Dissertação de Mestrado, Instituto de Geociências - USP)

; FERNANDES, L.A.; COIMBRA. A.M. 1990a. Evolução tectono-sedimentar ceno7.óica do baixo vale do Rio Ribeira do Iguape, SP. In: CONGRESSO BRASILEIRO DE GEOLOGIA, 36ㅇ., Natal, 1990. Anais ... Natal, SBG, v.5, p. 2.250-2.260.

; COIMBRA, A.M.; FERNANDES, L.A.; MORAES, M.C. 1990b. Redefinição da Formação Pariqüera-Açu, Cenozóico do Estado de São Paulo. In: CONGRESSO BRASILEIRO DE GEOLOGIA, 36., Natal, 1990. Anais ... Natal, SBG, v.1, p.324-338.

PASSEGA, R. 1957 Texture as characteristic of clastic deposition. Bulletin of the American Association of Petroleum Geologists, 41(9): 1952-1984.

1964 Grain size representation by CM patterns as a geological tool. Journal of Sedimentary Petrology, 34(4):830-847.

PETTIJOHN, F.J. 1975 Sedimentary rocks. 3 ed. New York. Harper \& Row. 628p.

PUFFER, J.H. \& COUSMINER, H. 1982 Factors controlling the accumulation of titanium-iron oxide-rich sands in the Cohansey Formation, Lakehurst area, New Jersey. Economic Geology, 77(2):379-391.

RICCOMINI, C. 1989 O Rift Continental do Sudeste do Brasil. São Paulo. (Tese de Doutoramento, Instituto de Geociências, USP)

RUST, B.R. 1983 Coarse alluvial deposits. In: WALKER, R.G. (Editor), Facies models. Hamilton, Geoscience Canada, p.9-21 (GC Reprint Series, 1).

SHEPARD, F.P. 1954 Nomenclature based on sand-silt-clay ratios. Journal of Sedimentary Petrology, 24:151-158.

SUGUIO, K. 1969 Contribuição à geologia da Bacia de Taubaté, Vale do Paraíba, Estado de São Paulo. São Paulo. 106p. (Tese de Doutorado, Faculdade de Filosofia, Ciências e Letras da Universidade de São Paulo). Publicada em Boletim Especial da FFCL/USP.

1973 Introdução à sedimentologia. São Paulo, Ed. Edgard Blücher/EDUSP. 317p.

TEMPLE, A.K. 1966. Alteration of ilmenite. Economic Geology, 61(4):695-714.

TEUFER, G. \& TEMPLE, A.K. 1966. Pseudorutile - a new mineral intermediat between ilmenite and rutile in the $\mathrm{N}$ alteration of ilmenite. Nature, 211(5045):179-181.

Trabalho realizado com apoio da FINEP.

\section{Endereço dos autores:}

Maria Cristina de Moraes, Sandra Garcia Gabas, Mário Sérgio de Melo e Luiz Alberto Fernandes - Instituto de Pesquisas Tecnológicas do Estado de São Paulo - IPT - Caixa Postal 7.141 - 05508 - São Paulo, SP - Brasil.

Armando Márcio Coimbra - Universidade de São Paulo - Instituto de Geociências - Caixa Postal 20.899 - 01498 - São Paulo, SP - Brasil. 